\title{
Analisis Kompetensi Pedagogik Guru Biologi SMA Di Kabupaten Aceh Tamiang
}

\author{
Mardiana $^{1}$, Fauziyah Harahap ${ }^{2 *}$, Syarifuddin ${ }^{3}$ \\ Sekolah Menengah Pertama Negeri 1 Bendahara, Aceh Tamiang \\ Program Studi Pendidikan Biologi, Program Pascasarjana, Universitas Negeri Medan \\ *Email: fauziyahharahap@gmail.com
}

\begin{abstract}
The objective of this study is to find out how biology teacher paedogogical competency of senior high schools in Aceh Tamiang regency. This study involved all of the high schools in Aceh Tamiang regency. The population in this studyconsist of 54 biology teachers in Aceh Tamiang regency. The sample of this study consist of 34 biology teachers. In this study, observation in high school class was done by using the instrument called Penilaian Kinerja Guru (PK Guru) which has been modified by researcher. This sutdy uses descriptif quantitatif research methode by using numbering and then the number is explained by using the sentences. The result of this study shows the paedogogical competency of biology teacher is verygood including some aspect : 1)recognize the student's characteristic is very good $(80,40 \%), 2)$ having the ability the theory of teaching learning process and technique is very good $(78,36 \%) 3)$. curiculum developing is very good $(77,33 \%) 4)$ teaching learning process is very good $(80,31 \%), 5)$ knowing and developing student ability is very good $(80,02 \%), 6)$ communicating with the student's is very good $(83,09 \%) 7)$ assessment and evaluation is very good(80,15\%). There are some obstacles that biology teachers should face regarding teaching, teachers have not been able to developing syllabus from BSNP based on students characteristics and condition of local region. In addition the result of study on curiculum developing to design worksheets and module obtained are very low 63\%, then in the aspects having the ability the theory of teaching learning process and technique the ability of teachers to invite students learn to recognize enviroment and provide oppurtunities for students to make observation and experiments were also obtained a low value $74 \%$.
\end{abstract}

Keyword: Analysis, Paedogogical Competence, Biology teacher

\section{PENDAHULUAN}

Pendidikan merupakan sarana strategis untuk meningkatkan kualitas suatu bangsa, karena kemajuan suatu bangsa dapat diukur dari kemajuan pendidikannya. Pendidikan juga dapat menjadi salah satu sarana yang efektif untuk meningkatkan dan mengembangkan kualitas sumber daya manusia melalui proses pembelajaran.

Menurut Kunandar (2011) salah satu faktor yang menentukan mutu dalam pendidikan adalah guru. Guru berada pada poisisi terdepan dalam meningkatkan kualitas sumber daya manusia karena gurulah yang berhadapan langsung dengan peserta didik dalam proses belajar mengajar. Berkat keahliannya sebagai guru, maka akan dilahirkan peserta didik yang berkualitas baik secara akademik, keahlian, kematangan emosional, moral dan spiritual. Sehingga mampu menghasilkan sumber daya manusia yang mampu menghadapi tantangan zaman.
Seorang guru yang profesional memiliki seperangkat kompetensi yang menjadi syarat untuk menopang tugas dan fungsinya sebagai guru. Guru yang profesional tidak hanya sekedar mengajar dan metode, tetapi juga harus mampu memotivasi peserta didik, memiliki kecakapan yang tinggi dan berwawasan luas (Suryadi, 2014).

Berdasarkan Undang-Undang Guru dan Dosen No. 14 tahun 2005 Pasal 2, seorang guru dikatakan sebagai tenaga profesional yang mengandung arti bahwa pekerjaan guru hanya dapat dilakukan oleh seseorang yang mempunyai kualifikasi akademik, kompetensi dan sertifikasi pendidik sesuai dengan persyaratan untuk setiap jenis dan jenjang pendidikan tertentu.

Kompetensi yang dijadikan dasar untuk penilaian kinerja guru adalah kompetensi pedagogik, profesional, sosial dan kepribadian, sebagaimana ditetapkan dalam Peraturan Menteri Pendidikan Nasional Nomor 16 Tahun 2007. Keempat kompetensi ini telah dijabarkan menjadi kompetensi guru yang harus dapat ditunjukkan 
dan diamati dalam berbagai kegiatan, tindakan dan sikap guru dalam melaksanakan pembelajaran atau pembimbingan(Anonim, 2010)

Kompetensi pedagogik merupakan kemampuan mengelola pembelajaran, mencakup konsep kesiapan mengajar yang ditunjukkan oleh penguasaan pengetahuan dan ketrampilan mengajar. Kompetensi ini harus dimiliki setiap guru agar tercapai keberhasilan dalam proses belajar dan mengajar ( Hasanuddin,2010).

Salah satu propinsi di Indonesia yang masih memiliki kendala dalam meningkatkan kualitas sumber daya manusia melalui pendidikan adalah Aceh. Hasil penelitian Majid (2014) menyatakan bahwa mutu pendidikan Aceh berada di atas rangking 25 dari 34 Provinsi di Indonesia.Pembangunan sektor pendidikan belum merata antar kabupaten/kota di Aceh.

Sedangkan menurut pengamat pendidikan Aceh, Dr. Nazamuddin Basyah, M.A yang juga sebagai Wakil Ketua Majelis Pendidikan Daerah (MPD) dan Pembantu Rektor Bidang Kerja Sama Unsyiah mengungkapkan bahwa permasalahan lain yang muncul dalam dunia pendidikan Aceh adalah kualitas guru yang masih rendah. Ini terbukti dari hasil uji kompetensi guru (UKG) 2013 bahwa guru di Aceh hanya mendapat nilai 40,66. Artinya, masih berada di bawah rata-rata nasional yang telah mencapai 47,84 (Anonim, 2014).

Berdasarkan data dari Dinas Pendididikan Aceh, nilai rata-rata UKG tahun 2013 untuk Kabupaten Aceh Tamiang adalah 40,41 berada di peringkat ke tujuh dari 23 kabupaten/kota yang ada di Aceh dan masih berada di bawah rata-rata nasional.

Namun hasil UKG yang telah dilaksanakan hanya berupa penilaian tes secara tertulis, belum dapat menunjukkan kesesuaian dengan kinerja guru di lapangan. Sehingga belum menggambarkan penilaian kompetensi secara utuh.Untuk itu perlu dilakukan penelitian kompetensi pedagogik guru secara utuh di lapangan dengan melakukan observasi.

\section{METODE}

Penelitian ini dilakukan pada guru biologi SMA di Kabupaten Aceh Tamiang yang berjumlah 34 orang mewakili kelas X,XI dan XII. Penelitian dilaksanakan mulai Maret sampai Agustus 2016. Teknik pengambilan sampel menggunakan teknik purposive samplingdengan mempertimbangkan letak sekolah secara geografis di wilayah Aceh Tamiang yang dapat dibagi pada tiga titik, yaitu wilayah hilir (pesisir), tengah (kota)dan hulu (pegunungan).

Tabel 1. Rincian Jumlah Guru Biologi yang Menjadi Responden

\begin{tabular}{llc}
\hline Letak Sekolah & Nama Sekolah & Jumlah Responden \\
\hline Wilayah Hilir & SMAN 1 Bendahara & 2 orang \\
& SMAN 1 Seruway & 2 orang \\
& SMAN 2 Seruway & 2 orang \\
Wilayah Tengah & SMAN 1 Manyak Payed & 3 orang \\
& SMAN 1 Karang Baru & 3 orang \\
& SMAN 2 Percontohan & 2 orang \\
& SMAN 1 Kejuruan Muda & 4 orang \\
Wilayah Hulu & SMAN 2 Kejuruan Muda & 3 orang \\
& SMAS Alwashliyah & 1 orang \\
& SMAS Darul Mukhlisin & 1 orang \\
& SMAN 1 Tamiang Hulu & 2 orang \\
Jumlah & SMAN 2 Tamiang Hulu & 2 orang \\
& SMAN 4 Kejuruan Muda & 3 orang \\
& SMAN 5 Kejuruan Muda & 3 orang \\
\hline
\end{tabular}

\section{Jenis Penelitian}

Penelitian ini menggunakan metode penelitian deskriptif kuantitatif dengan menggunakan angka kemudian dijelaskan dengan menggunakan kalimat.

\section{Instrumen Pengumpulan Data}

Penelitian ini adalah penelitian deskriptif yang bertujuan menggambarkan kompetensi pedagogik guru biologi di Kabupaten Aceh 
Tamiang. Instrumen penelitian yang digunakan berupa lembar observasi yang digunakan bertujuan melihat kegiatan pembelajaran guru dan mengevaluasi pembelajaran. Pengamatan yang dilakukan harus mengacu pada indikator yang telah tertuang dalam lembaran observasi. Kategori Instrumen yang digunakan untuk observasi di kelas menggunakan instrumen Penilaian Kinerja (PK) Guru yang sudah dimodifikasi dan divalidasi oleh validator Lembar observasi dibuat dengan menggunakan skala yang telah ditetapkan pada Penilaian Kinerja Guru (PK Guru).

Tabel 2. Kisi-kisi Instrumen Lembar Observasi Kompetensi Pedagogik Guru

\begin{tabular}{llc}
\hline No & Aspek yang diamati & Jumlah item \\
\hline 1 & Mengenal karakteristik Peserta Didik & 9 \\
2 & Menguasai teori Belajar dan prinsip-prinsip belajar yang mendidik & 7 \\
3 & Pengembangan Kurikulum & 6 \\
4 & Kegiatan pembelajaran yang mendidik & 9 \\
5 & Memahami dan Mengembangkan potensi peserta didik & 6 \\
6 & Komunikasi dengan peserta didik & 6 \\
7 & Penilaian dan Evaluasi & 5 \\
\hline
\end{tabular}

\section{Teknik Analisa Data}

Analisis data terhadap seluruh temuan di lapangan adalah untuk mengetahui kompetensi guru biologi SMA di Kabupaten Aceh Tamiang. Adapun langkah-langkah analisis data hasil adalah sebagai berikut:

\section{Skoring}

Skor terhadap kompetensi pedagogik menggunakan skala yang telah ditetapkan dalam penentuan PK Guru sesuai Peraturan Menteri Negara Pendayagunaan Aparatur Negara dan Reformasi BirokrasiNo. 16 Tahun 2009.yaitu:

1. Skor 1 menyatakan indikator tidak dilakukan

2. Skor 2 menyatakan indikator jarang dilakukan

3. Skor 3 menyatakan indikator dilakukan

4. Skor 4 menyatakan indikator sering dilakukan.

Perolehan skor untuk setiap kompetensi tersebut selanjutnya dijumlahkan dan dihitung persentasenya dengan cara: membagi total skor yang diperoleh dengan total skor maksimum kompetensi dan mengalikannya dengan $100 \%$.

\section{Tabulasi dan Analisa data}

Data yang diperoleh dari semua instrumen akan dianalisis dengan menggunakan rumus :

Keterangan:

$$
P=\frac{F}{N} x 100 \%
$$

$$
\begin{aligned}
& \mathrm{P}=\text { Persentase } \\
& \mathrm{F}=\text { Frekuensi } \\
& \mathrm{N}=\text { Jumlah }
\end{aligned}
$$

Selanjutnya penulis mengkategorikan kompetensi guru biologi berdasarkan skor yang diperoleh dari setiap instrumen yang digunakan. Berikut tabel kriteria analisis untuk masingmasing kompetensi.

Tabel 3. Kriteria Deskriptif Analisis Kompetensi Pedagogik

\begin{tabular}{cc}
\hline Nilai Hasil PK GURU & Kriteria \\
\hline $91-100$ & Amat baik \\
$76-90$ & Baik \\
$61-75$ & Cukup \\
$51-60$ & Sedang \\
$\leq 50$ & Kurang \\
\hline
\end{tabular}

\section{HASIL DAN PEMBAHASAN}

Secara keseluruhan rata-rata persentase hasil kompetensi pedagogik guru biologi SMA di Kabupaten Aceh Tamiang yang diamati meliputi tujuh aspek yaitu: 1) mengenal karakterisik peserta didik 2) Menguasai teori belajar dan prinsip pembelajaran, 3) Pengembangan kurikulum, 4) kegiatan pembelajaran yang mendidik, 5) Memahami dan 
mengembangkan potensi peserta didik, 6) Penilaian dan evaluasi tertera seperti pada Tabel Komunikasi dengan peserta didik dan 7) 4.

Tabel 4. Persentase Hasil Kompetensi Pedagogik Guru

\begin{tabular}{llcc}
\hline No & Aspek yang diamati & Persentase(\%) & Kriteria \\
\hline 1 & Mengenal karakteristik Peserta Didik & 80,40 & Baik \\
2 & Menguasai teori Belajar dan prinsip-prinsip belajar yang mendidik & 78,36 & Baik \\
3 & Pengembangan Kurikulum & 77,33 & Baik \\
4 & Kegiatan pembelajaran yang mendidik & 80,31 & Baik \\
5 & Memahami dan Mengembangkan potensi peserta didik & 80,02 & Baik \\
6 & Komunikasi dengan peserta didik & 83,09 & Baik \\
7 & Penilaian dan Evaluasi & 80,15 & Baik \\
\hline & Rata-Rata & 79,90 & Baik \\
\hline
\end{tabular}

Berdasarkan data hasil dari kompetensi pedagogik guru biologi di kabupaten Aceh Tamiang terlihat bahwa secara keseluruhan untuk aspek mengenal karakteristik peserta didik persentase rata-rata guru biologi SMA di Kabupaten Aceh Tamiang memiliki kriteria baik yaitu $80,40 \%$, dengan rincian kriteria $12,61 \%$ amat baik dan $87,38 \%$ baik

Adapun persentase rata-rata hasil penelitian tentang kompetensi pedagogik guru biologi SMA di kabupaten Aceh Tamiang berdasarkan aspek mengenal karakter peserta didik disajikan pada Tabel 5.

Tabel 5. Persentase Hasil Kompetensi Pedagogik Guru Biologi SMA di Kabupaten Aceh Tamiang Mengenal Karakter Peserta Didik

\begin{tabular}{llcc}
\hline No & \multicolumn{1}{c}{ Aspek yang diamati } & $\begin{array}{c}\text { Persentase } \\
\text { Responden (\%) }\end{array}$ & Kriteria \\
\hline 1 & $\begin{array}{l}\text { Mengenal karakter belajar peserta di kelasnya } \\
2\end{array}$ & 83 & Baik \\
& $\begin{array}{l}\text { Mengatur posisi tempat duduk siswa sesuai dengan kegiatan } \\
\text { pembelajaran }\end{array}$ & 81 & Baik \\
3 & $\begin{array}{l}\text { Berkeliling mensupervisi semua siswa } \\
\text { Mengantisipasi masalah yang muncul dalam pemebelajaran }\end{array}$ & 76 & Baik \\
5 & $\begin{array}{l}\text { Memberikan kesempatan belajar pada siswa sesuai dengan caranya } \\
\text { masing-masing }\end{array}$ & 77 & Baik \\
6 & $\begin{array}{l}\text { Melakukan pengecekan secara rutin bahwa semua siswa secara aktif } \\
\text { melakukan tugas yang diberikan }\end{array}$ & 79 & Baik \\
7 & $\begin{array}{l}\text { Melakukan penegecekan secara rutin dengan bertanya pada siswa } \\
\text { tentang keterbacaan media yang digunakan }\end{array}$ & 79 & Baik \\
8 & $\begin{array}{l}\text { Membuat catatan tentang kemajuan siswa } \\
\text { Melakukan komunikasi tentang karakter siswa kepada wali kelas }\end{array}$ & 91 & Baik \\
\hline Rata-rata & $\mathbf{8 0 . 4 0}$ & Amat Baik \\
\hline
\end{tabular}

Untuk kompetensi pedagogik guru dalam menguasai teori belajar dan prinsip-prinsip belajar yang mendidik ada tujuh aspek yang diamati dan hasil persentase rata-rata perolehan nilai kompetensi pedagogik guru dalam aspek menguasai teori belajar yang mendidik dapat dilihat pada Tabel 6 berikut ini.

Tabel 6. Persentase Hasil Kompetensi Pedagogik Guru Dalam Menguasai Teori Belajar dan Prinsipprinsip Belajar yang Mendidik

\begin{tabular}{|c|c|c|c|}
\hline No & Aspek yang diamati & $\begin{array}{c}\text { Persentase } \\
\text { Responden } \\
(\%)\end{array}$ & Kriteria \\
\hline 1 & Menyampaikan materi secara runtut & 83 & Baik \\
\hline
\end{tabular}




\begin{tabular}{|c|c|c|c|}
\hline No & Aspek yang diamati & $\begin{array}{c}\text { Persentase } \\
\text { Responden } \\
(\%)\end{array}$ & Kriteria \\
\hline 2 & Mengajarkan konsep keilmuan sesuia dengan konteks kehidupan sehari-hari & 78 & Baik \\
\hline 3 & Mengajak siswa belajar dengan mengenal aplikasi di lingkungan sekita & 74 & Baik \\
\hline 4 & Menghubungkan hal-hal baru dengan pengetahuan awal siswa & 79 & Baik \\
\hline 5 & $\begin{array}{l}\text { Memberikan kesempatan kepada sisiwa untuk melakukan pengamatan atau } \\
\text { eksperimen }\end{array}$ & 74 & Baik \\
\hline 6 & Merencanakan kegiatan pembelajaran yang saling terkait satu sama lainnya & 82 & Baik \\
\hline 7 & $\begin{array}{l}\text { Memperhatikan respon peserta didik yang belum/ kurang memahami materi } \\
\text { dan menggunakannya untk memperbaiki RPP berikutnya }\end{array}$ & 79 & Baik \\
\hline \multicolumn{2}{|c|}{ Rata-rata } & 78,36 & Baik \\
\hline
\end{tabular}

Secara keseluruhan kompetensi pedagogik untuk aspek menguasai teori belajar dan prinsip belajar yang mendidik terdiri dari tujuh item aspek yang diamati diperoleh persentase rata-rata dengan berkriteria baik dengan rincian yaitu : $8,82 \%$ amat baik dan dan $91,17 \%$ baik
Sedangkan untuk hasil kompetensi pedagogik guru untuk aspek pengembangan kurikulum diperoleh $21,12 \%$ amat baik, $65,73 \%$ baik dan 13,36\% cukup. Adapun data hasil kompetensi pedagogik untuk pengembangan kurikulum dapat terlihat pada seperti pada Tabel 7.

Tabel 7 Persentase Hasil Kompetensi Pedagogik Guru dalam Aspek Pengembangan Kurikulum

\begin{tabular}{llcc}
\hline No & \multicolumn{1}{c}{ Aspek yang diamati } & $\begin{array}{c}\text { Persentase } \\
\text { Responden (\%) }\end{array}$ & Kriteria \\
\hline 1 & $\begin{array}{l}\text { Menyusun silabus sesuai dengan kurikulum } \\
\text { Menyusun RPP lengkap baik untuk kegiatan di kelas, Lab. dan } \\
\text { lapangan } \\
\begin{array}{l}\text { Memilih materi pelajaran sesuia dengan tujuan dan konteks } \\
\text { kehidupan sehari-hari } \\
\text { Mengikuti urutan materi pembelajaran dengan memperhatikan } \\
\text { tujuan pembelajaran }\end{array}\end{array}$ & 98 & $\begin{array}{c}\text { Amat Baik } \\
\text { Baik }\end{array}$ \\
5 & $\begin{array}{l}\text { Merancang LKS atau modul } \\
6\end{array}$ & 76 & Baik \\
\hline Mata-rata & 63 & Baik \\
\hline
\end{tabular}

Untuk kompetensi pedagogik dalam aspek kegiatan pembelajaran yang mendidik maka dapat terlihat hasil pada Tabel 8 .

Tabel 8. Persentase Hasil Kompetensi Pedagogik Kegiatan Pembelajaran yang Mendidik

\begin{tabular}{|c|c|c|c|}
\hline No & Aspek yang diamati & $\begin{array}{c}\text { Persentase } \\
\text { Responden }(\%)\end{array}$ & Kriteria \\
\hline 1 & Melaksanakan pembelajaran sesuia RPP & 84 & Baik \\
\hline 2 & Menyampaikan materi pembelajaran dengan lancar & 82 & Baik \\
\hline 3 & $\begin{array}{l}\text { Melaksanakan kegiatan pembelajaran sesuai kurikulum dan mengaitkannya } \\
\text { dengan kehidupan sehari-hari siswa }\end{array}$ & 78 & Baik \\
\hline 4 & Melakukan aktifitas secara bervariasi dengan waktu yang cukup & 79 & Baik \\
\hline 5 & Mengelola kelas dengan efektif & 80 & Baik \\
\hline 6 & $\begin{array}{l}\text { Mampu menyesuaikan aktifitas pembelajaran yang dirancang dengan kondisi } \\
\text { kelas }\end{array}$ & 78 & Baik \\
\hline 7 & $\begin{array}{l}\text { Memberikan kesempatan kepada siswa untuk bertanya, mempraktekkan dan } \\
\text { berinteraksi dengan siswa lain }\end{array}$ & 82 & Baik \\
\hline 8 & Mengatur kegiatan pembelajaran dengan sitematis & 77 & Baik \\
\hline
\end{tabular}


9 Menggunakan alat bantu berupa media pembelajaran untuk meningkatkan motivasi siswa

$$
\text { Rata-rata }
$$

Untuk aspek kegiatan pembelajaran yang mendidik diperoleh hasil dengan kriteria amat baik sebesar 2,94\%, 82,35\% baik dan 14,70\% kriteria cukup. Namun secara keseluruhan untuk aspek ini memperoleh kriteria baik. Adapun data untuk aspek memahami dan mengembangkan potensi peerta didik dapat dilihat pada Tabel 9 .

Tabel 9. Persentase Hasil Kompetensi Pedagogik Guru Dalam Memahami dan Mengembangkan potensi peserta didik

\begin{tabular}{llcc}
\hline No & \multicolumn{1}{c}{ Aspek yang diamati } & $\begin{array}{c}\text { Persentase } \\
\text { Responden (\%) }\end{array}$ & Kriteria \\
\hline 1 & Memberi perhatian kepada seluruh siwa & 89 & Baik \\
2 & Memberikan perhatian terhadap kontribusi siswa & 76 & Baik \\
3 & $\begin{array}{l}\text { Merancang dan melaksanakan aktifitas pembela yang mendidijaran } \\
\text { untuk memunculkan kreatifitas dan berfikir kritis }\end{array}$ & 77 & Baik \\
4 & $\begin{array}{l}\text { Memotivasi siswa untuk bertanya tentang topik yang dibahas } \\
\text { Memotivasi siswa untuk mengembankan pemikiran dan }\end{array}$ & 84 & Baik \\
& $\begin{array}{l}\text { pengalamannya yang melebihi pengetahuan dan pengalamannya } \\
\text { dalam kehidupan sehari-hari }\end{array}$ & 76 & Baik \\
6 & Meyakinkan siswa terlibat aktif dalam pembelajaran & 77 & Baik \\
\hline Rata-rata & $\mathbf{8 0 . 0 2}$ & Baik \\
\hline
\end{tabular}

Untuk aspek memahami dan mengembangkan potensi peserta didik diperoleh hasil 2,94\% dengan kriteria amat baik, $85,29 \%$ kriteria baik dan $11,76 \%$ dengan kriteria cukup. Namun secara keseluruhan untuk aspek ini diperoleh persentase rata-rata dengan kriteria baik. Adapun data hasil persentase rata-rata untuk kompetensi pedagogik dalam aspek komunikasi dengan peserta didik dapat terlihat pada Tabel 10.

Tabel 10. Persentase hasil kompetensi pedagogik guru dalam aspek komunikasi dengan peserta didik

\begin{tabular}{|c|c|c|c|}
\hline No & Aspek yang diamati & $\begin{array}{c}\text { Persentase } \\
\text { Responden }(\%)\end{array}$ & Kriteria \\
\hline 1 & $\begin{array}{l}\text { Memberikan pertanyaan untuk mengetahui pemahaman dan menjaga } \\
\text { partisipasi siswa }\end{array}$ & 94 & Baik \\
\hline 2 & $\begin{array}{l}\text { Memberikan perhatian dan mendengarkan semua pertanyaan dan } \\
\text { responsiswa tanpa menginterupsi kecuali diperlukan }\end{array}$ & 93 & Baik \\
\hline 3 & $\begin{array}{l}\text { Merespon pertanyaan siswa sesuia dengan tujuan pembelajaran tampa } \\
\text { mempermalkannya }\end{array}$ & 76 & Baik \\
\hline 4 & Memastikan seluruh siswa berpartisipasi aktif dalam pembelajaran & 79 & Baik \\
\hline 5 & $\begin{array}{l}\text { Merespon jawaban siswa dan mendorong siswa bekerjasama dalam } \\
\text { menjawab pertanyaan }\end{array}$ & 78 & Baik \\
\hline 6 & $\begin{array}{l}\text { Memberikan perhatian terhadap pertanyaan siswa dan memberikan } \\
\text { jaawaban secara lengkap }\end{array}$ & 77 & Baik \\
\hline \multicolumn{2}{|c|}{ Rata-rata } & 83.09 & Baik \\
\hline
\end{tabular}

Secara keseluruhan untuk kompetensi pedagogik dalam aspek komunikasi dengan peserta didik diperoleh hasil rata-rata baik. Adapun rinciannya adalah sebagai berikut: Untuk hasil kriteria amat baik diperoleh nilai 2,94\%, untuk kruteria baik diperoleh nilai $94,11 \%$ dan kriteria cukup diperoleh nilai 2,94\%. Adapun data untuk kompetensi pedagogik dalam aspek 
penilaian dan evaluasi yang terdiri dari lima item aspek yang diamati, maka diperoleh hasil persentase rata -rata seperti pada Tabel 11.

Tabel 11. Pesentase hasil kompetensi pedagogik guru dalam penilaian dan evaluasi

\begin{tabular}{|c|c|c|c|}
\hline No & Aspek yang diamati & $\begin{array}{c}\text { Persentase } \\
\text { Responden }(\%)\end{array}$ & Kriteria \\
\hline 1 & $\begin{array}{l}\text { Menyusun penilaian yang sesuia dengan tujuan pembelajaran untuk mencapai } \\
\text { tujuan seperti tertulis dalam RPP }\end{array}$ & 77 & Baik \\
\hline 2 & $\begin{array}{l}\text { Mengkomunikasikan hasil penilaian kepada siswa dengan menunjukkan materi } \\
\text { yang belum dikuasai peserta didik }\end{array}$ & 75 & Baik \\
\hline 3 & $\begin{array}{l}\text { Memiliki hasil analisis penilaian dan menunjukkan topik yang sulit untuk } \\
\text { keperluan remedial }\end{array}$ & 96 & Baik \\
\hline 4 & $\begin{array}{l}\text { Melakukan refleksi pembelajaran dengan membuktikannya melalui catatan atau } \\
\text { jurnal }\end{array}$ & 76 & Baik \\
\hline 5 & $\begin{array}{l}\text { Memanfaatkan hasil penilaian sebagai bahan penyusun RPP yang akan dilakukan } \\
\text { selanjutnya }\end{array}$ & 76 & Baik \\
\hline \multicolumn{2}{|c|}{ Rata-rata } & 80,15 & Baik \\
\hline
\end{tabular}

Sedangkan untuk kompetensi pedagogik guru dalam aspek penialain dan evaluasi diperoleh hasil 29,41\% dengan kriteria amat baik ,85,29\% dengan kriteria baik dan $11,76 \%$ kriteria cukup.

Secara keseluruhan hasil penelitian kompetensi pedagogik guru biologi SMA di Kabupaten Aceh Tamiang secara keseluruhan memiliki kriteria baik. Hal ini dapat disebakan karena kegiatan Musyawarah Guru Mata Pelajaran (MGMP) di Kabupaten Aceh Tamiang cukup aktif meskipun dengan biaya mandiri dari peserta.Kegiatan MGMP yang dilaksanakan satu minggu sekali cukup membantu para guru dalam meningkatkatkan kompetensinya.

Musyawarah Guru Mata Pelajaran (MGMP) merupakan suatu wadahyang disediakan bagi para guru mata pelajaran sejenis untuk memecahkanberbagai persoalan yang dihadapi dalam upaya peningkatan kualitasprofesionalnya.Untuk mewujudkan peran MGMP dalam pengembanganprofesionalisme guru maka peningkatan kinerja MGMP merupakan masalah yangmendesak untuk dapat direalisasikan (Sudirman, 2010).

Selain itu kompetensi pedagogik guru juga dapat meningkatkan motivasi belajar siswa.Kompetensi pedagogik guru dalam meningkatkan motivasi belajar siswa di SMPN 3 Ingin Jaya Kabupaten Aceh Besar dapat dilakukan dengan berbagai cara, yaitu: (a) memanfaatkan teknologi informasi dan komunikasi untuk kepentingan pembelajaran dilakukan dengan memberi kesempatan kepada peserta didik untuk terlibat aktif dalam menggunakan fasilitas teknologi informasi dan komunikasi dalam pencapaian tujuan pembelajaran, (b) berkomunikasi secara efektif, empatik, dan santun dengan peserta didik dilakukan setiap hari kerja dengan memberi sapaan dan teguran yang bersifat mendidik dan memperbaiki tingkah laku peserta didik, dan (c) melakukan tindakan reflektif untuk peningkatan kualitas pembelajaran yang dilakukan dengan tes diagnostik untuk setiap materi pelajaran yang sudah diajarkan (Balqis,dkk2014).

Berdasarkan hasil penelitian menunjukkan bahwa dari ketujuh aspek yang diamati dalam kompetensi pedagogik guru aspek komunikasi dengan peserta didik memiliki persentase tertinggi Ini menunjukkan bahwa guru mampu membina hubungan yang baik dengan siswa sehingga dengan komunikasi yang baik ini diharapkan siswa dapat dengan mudah menerima materi pelajaran.

Kompetensi pedagogik berhubungan langsung dengan keterampilan guru dalam kegiatan belajar mengajar,dengan keterampilan guru dalam menciptakan iklim komunikatifdiharapkan siswa dapat berpartisipasi 
aktif untuk mengeluarkan pendapatnya,mengembangkan imajinasinya dan daya kreativitasnya. Tentu komunikasi gurudan siswa yang dimaksud adalah dalam kegiatan pembelajaran tatap muka baiksecara verbal maupun non verbal, baik secara individual maupun kelompok dandibantu dengan media atau sumber belajar

Untuk mencapai interaksi belajar mengajar yang efektif perlu adanya komunikasi yang jelas antara guru sebagai pendidik dengan siswa sebagai peserta didik. Sehingga terpadunya dua kegiatan, yakni kegiatan mengajar sebagai usaha guru dengan kegiatan belajar yang menjadi tugas siswa untuk mencapai tujuan pembelajaran.

Baiknya relasi guru dan siswa menjadi prasyarat utama terciptanya proses pembelajaran yang efektif. Guru dan siswa merupakan pelaku utama dalam proses pembelajaran. Kedua pelaku ini menjalankan peran penting dalam mencapai tujuan pembelajaran yang dilangsungkan di sekolah.Oleh sebab itu, di antara kedua pelaku utama ini sudah semestinya terjalin relasi edukasi yang baik (Iriantara, 2013).

Guru selain harus bisa komunikasi dengan siswa juga dituntut dapat mengelola kelas. Pengelolaan kelas merupakan prasyarat mutlak bagi terjadinya proses pembelajaran yang efektif dengan cara menciptakan situasi yang kondusif. Suatu kondisi belajar yang kondusif dapat tercapai jika guru mengatur peserta didik dan sarana pengajaran serta mengendalikannya dalam suasana yang menyenangkan untuk mencapai tujuan pengajaran, serta hubungan interpersonal yang baik antara guru dan peserta didik, peserta didik dengan peserta didik. Beberapa prinsip yang harus diperhatikan guru dalam pengelolaan kelas adalah tantangan, kehangatan dan keantusiasan, berfariasi, keluwesan, penekanan pada hal yang positif dan penanaman disiplin diri (Mulyono, 2014).

Sedangkan untuk aspek terendah adalah pengembangan kurikulum namun masih dalam kategori baik.Pada aspek pengembangan kurikulum nilai terendah adalah pada kemampuan guru merancang LKS atau modul yaitu 62.Ini menunjukkan bahwa kemampuan guru merancang LKS atau modul masih rendah.

Pengembangan kurikulum ini meliputi kemampuan guru dalam menyusun silabus, merancang rencana pelaksanaan pembelajaran, memilih materi pembelajaran yang sesuai dengan tujuan pembelajaran sesuai dengan tingkat kemampuan siswa, mutakhir dan sesuai dengan konteks kehidupan sehari-hari.

Sebagaimana diketahui guru merupakan titik sentral dalam pendidikan, yaitu sebagai ujung tombak dilapangan dalam pengembangan kurikukulum. Keberhasilan belajar mengajar antara lain ditentukan oleh kemampuan professional danpribadi guru. Dikarenakan pengembangan kurikulum bertitik tolak dari dalam kelas, guru hendaknya mengusahakan gagasan kreatif dan melakukan uji coba kurikulum dikelasnya.Ini merupakan suatu fase penting dalam upayapengembangan kurikulum, disamping sebagai unsur penunjang admistrasi secara keseluruhan.

Silabus adalah rencana pembelajaran pada suatu dan/ ataukelompok mata pelajaran / tema tertentu yang mencakup SK, KD, materi pokok/pembelajaran, kegiatan pembelajaran, indikator pencapaian kompetensi untuk penilaian, penilaian, alokasi waktu dan sumber belajar (BSNP, 2006).

Silabus adalah adalah rencana pembelajaran yang memuat bahan/materi pelajaran tertentu yang mencakup SK, KD, materi pelajaran, indikator pencapaian, alokasi waktu dan sumber belajar yang dikembangkan oleh setiap satuan pendidikan sesuai dengan karakteristik peserta didik dan kebutuhan daerah.

Kenyataan di lapangan ditemukan masih banyak guru yang menggunakan silabus yang diadopsi dari internet dan buku-buku mata pelajaran dari berbagai penerbit yang dilengkapi dengan pengembangan silabus dan RPP. Pada umumnya pembuatan silabus juga dilakukan oleh MGMP (Musyawarah Guru Mata Pelajaran) yang melibatkan beberapa guru mata pelajaran serumpun yang isinya tidak jauh berbeda (hampir sama) dengan buku-buku yang dijual kesekolahsekolah. Sehingga silabus yang dibuat MGMP belum tentu sesuai dengan kondisi siswa, sekolah, dan daerah.Hal itu dapat menghambat aktivitas dan kreativitas siswa. Selanjutnya proses belajar mengajar menjadi monoton dan tidak berlangsung secara interaktif inspiratif menyenangkan, dan menentang. Untuk itu guru diharapkan bisa aktif dan kreatif merancang silabus yang sesuai dengan kondisi siswa, sekolah, dandaerah masingmasing. (Kendarti 2011).

Oleh karena itu meskipun pengembangan silabus dan RPP dapat dibuat bersama di MGMP, akan lebih baik lagi jika guru kemudian menyesuaikan dengan kondisi siswa di 
daerahnya. Silabus sangat bermanfaat sebagai pedoman dalam pengembangan pembelajaran lebih lanjut, seperti pembuatan RPP, pengelolaan kegiatan pembelajaran dan pengembangan sistem penilaian.Silabus merupakan sumber pokok dalam penyusunan RPP.Silabus juga digunakan sebagai pedoman dalam melaksanakan kegiatan pembelajaran, baik pembelajaran secara klasikal maupun individual.

Setiap guru harus mampu rnengernbangkan silabus secara mandiri sebagainaana diamanatkan dalam permendiknas 19 tahun 2007 yaitu setiap guru bertanggung jawab menyusun silabus mata pelajaran yang diampunya sesuai dengan standar isi (SI), standar kompetnsi lulusan (SKL) dan panduan penyusunan KTSP. Sebelum mengembangkan silabus guru harus melakukan analisis atau pemetaan SK dan KD agar sesuai dengan tuntutan kompetensi mata pelajaran. Selain masalah penyusun silabus masalah lain adalah rendahanya kemampuan guru dalam menyusun Lembar Kerja Siswa (LKS) atau modul bagi siswa yang disusun oleh guru sendiri masih rendah.Sebenarnya penggunaan LKS dalam pembelajaran oleh guru biasanya tidak berdiri sendiri atau tidak menjadi bahan ajar utama dan satu-satunya untuk pembelajaran sebuah materi.

Guru biasanya mengkombinasikan LKS dengan penggunaan buku paket atau buku teks pelajaran agar semakin sempurna. Namun LKS banyak dipilih oleh guru karena cukup mampu untuk menyajikan materi pelajaran yang hendak disampaikan dan disertai pula dengan latihan dan evaluasi yang cukup banyak (Prastowo 2013). Untuk melatih guru agar lebih terampil membuat LKS atau modul sebaiknya guru biologi SMA di Aceh Tamiang diberikan pelatihan untuk pembuatan LKS atau modul.Sehingga dalam kegiatan pembelajaran guru dapat menggunakan LKS atau modul yang dibuatnya sendiri.Pelatihan dapat dibuat di MGMP atau pelatihan khusus yang dibuat oleh Dinas Pendidikan.

Melalui penelitian ini untuk aspek menguasai teori belajar dan prinsip-prinsip pembelajaran yang mendidik juga ditemukan nilai rendah untuk pengamatan pada mengajak siswa belajar mengenal aplikasi di lingkungan sekitar dan memberikan kesempatan siswa untuk melakukan pengamatan atau eksperimen yaitu 74\% namun masih kategori baik. Penggunaan lingkungan sekitar sekolahseharusnya dapat digunakan sebagai tambahan laboratorium IPA dan menjadi media belajar bagi siswa. Pembelajaran di luar kelas akanmeningkatkan pencapaian pembelajaran melalui kemampuan mengorganisasi, pendekatan yang lebih baik karena belajar dari obyek langsung merupakan satu hal yang penting.

\section{SIMPULAN}

Hasil penelitian analisis data kompetensi pedagogik guru biologi SMA di Kabupaten Aceh Tamiang secara keseluruhan memiliki kategori baik. Untuk aspek mengenal karakteristik peserta didik termasuk baik (80,40\%), menguasai teori belajar dan prinsipprinsip pembelajaran yang mendidik baik ( $78,36 \%)$, pengembangan kurikulum kategori baik $(77,33 \%)$, kegiatan pembelajaran yang mendidik baik $(80,31 \%)$, memahami dan mengembangkan potensi peserta didik baik $(80,02 \%)$, komunikasi dengan peserta didik baik $(83,09 \%)$ serta penilaian dan evaluasi baik $(80,15 \%)$. Namun masih ada kendala yang dihadapi guru biologi dalam mengajar yaitu belum mampu mengembangkan silabus dari BSNP berdasarkan karakteristik siswa dan kondisi daerah setempat. Selain itu dari hasil penelitian pada aspek pengembangan kurikulum untuk merancang LKS dan modul diperoleh nilai sangat rendah $63 \%$, selanjutnya pada aspek menguasai teori belajar dan prinsip-prinsip belajar yang mendidik untuk kemampuan guru mengajak siswa belajar dengan mengenal aplikasi lingkungan sekitar dan memberikan kesempatan pada siswa untuk melakukan pengamatan dan eksperimen juga deroleh nilai yang rendah $74 \%$

\section{DAFTAR PUSTAKA}

Anonim.2010. Pembinaan Dan Pengembangan Profesi Guru Buku 2 (Pedoman Pelaksanaan Kinerja Guru).Jakarta : Kementerian Pendidikan dan Kebudayaan. Pusat Pengembangan Profesi Pendidik.

Anonim, 2014.Kualitas Guru Aceh Masih Rendah.Serambi Indonesia. Hlm.3

Balqis, P. Usman, N. Ibrahim, S. 2014. Kompetensi Pedagogik Guru Dalam Meningkatkan Motivasi Belajar Siswa Pada SMPN 3 Ingin Jaya Dikabupaten Aceh Besar. Jurnal Administrasi Pendidikan Pascasarjana Universitas Syiah Kuala. 2(1). 25-38 
BSNP. 2006. Panduan Penyusunan Kurikulum Tingkat Satuan Pendidikan Jenjang Pendidikan Dasar Dan Menengah. Jakarta.

Dinas Pendidikan Provinsi Aceh (online) http://disdik.acehprov.go.id/kiprahutama/pengelolaan-pendidikan-belum maksimal/diakses pada 10/11/2015.

Hasanuddin dan Nurmaliah,C .2010.Kompetensi Pedagogik Guru Biologi Yang Telah LulusSertifikasi Di SMA Negeri Kota Banda Aceh. Jurnal Pendidikan Serambi Ilmu. 9 (2). 108-121

Iriantara.Yosal dan Syaripudin. 2013. Komunikasi Pendidikan. Bandung : PT Remaja Rosda Karya

Mulyono.2014. Pengaruh Komunikasi Guru Dalam Mengelola Kelas Terhadap Prestasi Belajar Pkn.Jurnal Ilmiah Ppkn Ikip Veteran Semarang (1). $90-114$
Kendarti (2011) .Pendampingan Pengawas Sekolah Untu Meningkatkan Kemampuan Guru Menyusun Silabus.Jurnal llmiah Guru "COPE".(11).10-18

Kunandar.2011.Guru Profesional Implementasi Kurikulum Tngkat SatuanPendidikan (KTSP) dan Sukses Dalam Sertifikasi Guru.Jakarta : RajawaliPress

Prastowo, Andi 2013.Panduan Kreatif Membuat Bahan ajar Inovatif. Jogjakarta. Diva Press

Sudirman, 2010. Peranan MGMP Pendidikan Kewarganegaraan (PKN) dalam Meningkatkan Profesionalisme Guru SMA di Kota Malang.Jurnal Pendidikan Kewarganegaraan Universitas Negeri Malang.1(1) 22-30

Suryadi, A. 2014.Pendidikan Indonesia Menuju 2025.Jakarta: Remaja Rosda Karya. 